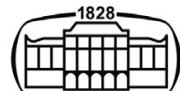

AKADÉMIAI KIADÓ

UNIVERSITY of DEBRECEN

\section{International Review of Applied Sciences and Engineering}

$12(2021) 3,230-237$

DOI:

10.1556/1848.2021.00262

(c) 2021 The Author(s)

\title{
Effect of the manufacturing parameters on the pore size and porosity of closed-cell hybrid aluminum foams
}

\author{
Hamid Ali $^{1}$, András Gábora ${ }^{1}$, Muhammad Ali Naeem ${ }^{1}$, \\ Gábor Kalácska ${ }^{2}$ and Tamás Mankovits ${ }^{1 *}$ \\ ${ }^{1}$ Department of Mechanical Engineering, Faculty of Engineering, University of Debrecen, Ótemeto” \\ Street 2-4, 4028 Debrecen, Hungary \\ ${ }^{2}$ Faculty of Mechanical Engineering, Szent István University, Páter Károly Street 1, 2100 Gödöllő, \\ Hungary
}

Received: February 20, 2021 • Accepted: April 24, 2021

Published online: July 1, 2021

\section{ORIGINAL RESEARCH PAPER}

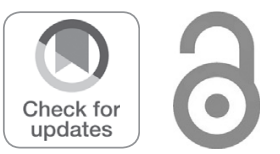

*Corresponding author.

E-mail: tamas.mankovits@eng.unideb. hu

\begin{abstract}
Over the recent years metallic foams have become a popular material due to their unique characteristics like low density coupled with beneficial mechanical properties such as good energy absorption, heat resistance, flame resistance, etc. However, their production processes (foaming) is highly stochastic which results in an inhomogeneous foam structure. Hybrid aluminum foam with closed-cell has been manufactured using direct foaming method coupled with the Taguchi Design of Experiments (DOE). Image analysis has been carried out to determine the average porous area and pore size. The influence of the production parameters (amount of foaming agent added, mixing speed and temperature) on the pore size and the porous area has been analyzed using the statistical Taguchi technique. From the experiments it was seen that the most important control factor for both the pore size and the porous area is the amount of the foaming agent added, followed by temperature and stirring speed. Furthermore, the statistical significance of these manufacturing parameters on the response was also investigated by performing analysis of variance (ANOVA) statistical method.
\end{abstract}

\section{KEYWORDS}

direct foaming, closed-cell hybrid metallic foam, manufacturing parameters, image analysis, porosity

\section{INTRODUCTION}

Metallic foams have many good properties due to the existence of pores in their composite structures such as low density, sound insulation performance and good energy absorption, low thermal conductivity, etc. [1-7]. Over recent years, these properties have driven them to the forefront of technological growth, especially in the fields where material density is a key concern. These structures are high specific strength porous solids which have a highly complex interconnecting microstructure. Metallic foams can accomodate large deformations. Because of their low density and high impact absorption $[8,9]$, concentrated densification on impact $[10,11]$, and lower thermal conductivity [12], they have numerous applications in various industries. These mechanical characteristics, however, mainly depend on several geometrical properties [13]. The characteristics, properties and current applications of existing cellular materials have been discussed in [14].

The inhomogeneity of metallic foams resulting from the stochastic nature of the manufacturing is a limitation in their application. Current research focuses on improving process control factors for the development of good quality and a more homogeneous cellular structure. 
Metallic foams were first reported in 1926 [15]. Most of the research on metallic foams seems to have been investigated on the mainly empirical basis without detailed analysis of the foaming process [16].

Metallic foams can be primarily classified into two categories, according to their cellular structure open cell or closed cell metallic foams. These two forms can be manufactured through different techniques and by using different materials, see in [17]. Nearly all of the manufacturing methods existing today and many of the metallic foams developed today are manufactured by one of the nine processes or their combination.

Aluminum foams are the most frequently produced metallic foams due to their unusual combination of mechanical properties (good energy and sound absorption, low density), see in [18]. The foaming agents and the manufacturing parameters used in the production of aluminum foams are presented in [19] which also offers a review of their advantages and the issues relevant to their use. There are also studies available on a special class of metallic foam called metal matrix syntactic foam. The microstructural characteristics of syntactic foams have been investigated in [20] and mechanical properties of aluminum matrix syntactic foam have been discussed in [21]. Hybrid foams are foam structures which are reinforced by particles.

The methods for the preparation of the samples were analyzed in [22] taking into consideration the particular use of the experiments to research the cell structure of metallic materials. A lot of information on the physical properties of metallic foams can be collected, and their impact and outcomes can be extracted from literature. The fatigue and fracture behavior of cellular structures with consideration of their fabrication and mechanical characterization has been studied in [23-26].

The manufacturing process has a significant influence on the characteristics of aluminum foams. There are several factors which decide about the material's response. The influence of the human aspect on the quality assurance of metallic foams was examined in [27]. The influence of the specific processing parameters was explored and the process optimization practices were discussed in [28, 29]. New manufacturing processes of metal foams were introduced in $[30,31]$.

Numerous methods exist in the literature for optimizing the technical problem. The Taguchi method is one of such experimental methodologies which determines the minimum number of experiments which are to be performed within the permissible limit of factors and levels. It makes use of orthogonal arrays to optimize the process and to develop the quality of the manufactured products by investigating the entire parameter space through a few experiments only. The approach has already been utilized in numerous manufacturing processes and operations such as drilling [32], wire electric discharge machining [33], waste water treatment [34] and casting [35].

In the scope of this research, closed cell aluminum foam specimens have been manufactured by direct foaming considering the Taguchi design of experiments (DOE) principles. The average pore size and the porous area of the samples have been determined through image analysis and the influence of manufacturing parameters (foaming content, mixing speed and temperature) on the average pore size and porous area have been analyzed. Analysis of variance (ANOVA) statistical method has also been performed on the porous area to calculate these parameters' statistical significance.

\section{METHODS AND MATERIALS}

Duralcan F3S.20S Metal Matrix Composite (MMC) was the primary raw material used to produce the metallic foam specimens. The material already contains the $\mathrm{SiC}$ particles, which are needed for stability and the complete chemical composition of the matrix content is calculated by means of an EDX analysis, the results of which are described in [36]. The chemical composition of the applied MMC is $69 \% \mathrm{Al}$, $9 \% \mathrm{Si}, 21 \% \mathrm{SiC}$ and others. Moreover, the $\mathrm{SiC}$ particles strengthen the matrix materials, resulting in a hybrid foam structure. In addition, a $\varnothing 3 \mu \mathrm{m}$ average particle size titanium hydride $\left(\mathrm{TiH}_{2}\right)$ powder was used as a foaming agent for production.

The specimens for the research were manufactured by the direct foaming technique under normal atmospheric pressure and temperature. The procedure to make the foam was carried out as the Authors introduced in [37]. Aluminum composite billets were added into the furnace and melted after which the foaming agent $\left(\mathrm{TiH}_{2}\right)$ was also added and stirred using a preheated 1.4301 steel mixing head [37]. Furthermore, the time for stirring was kept constant for all production samples.

During the mixing, the $\mathrm{TiH}_{2}$ separates into $\mathrm{Ti}$ and $\mathrm{H}_{2}$, the creation of which causes the melt to expand resulting in the formation of pores [37]. Once the stirring process is stopped and the foaming process is complete, the metal foam is cooled down using water to stabilize the formed bubbles before they collapse. The end result is a hybrid closed cell aluminum foam structure.

There are several manufacturing parameters which may have influence on the porosity of the aluminum foams. Table 1 shows the experimental process parameters and their respective level values which are used in the scope of this study.

The levels are selected according to the professional literature [27-29]. The temperature, the amount of foaming agent and the mixing speed are the manufacturing parameters.

Table 1. Factors and levels [37]

\begin{tabular}{lccc}
\hline Factors & Level 1 & Level 2 & Level 3 \\
\hline Temperature $\left({ }^{\circ} \mathrm{C}\right)$ & 700 & 800 & 850 \\
$\mathrm{TiH}_{2}$ fraction $(\mathrm{wt} \%)$ & 1.0 & 1.5 & 2.0 \\
Mixing speed $(\mathrm{rpm})$ & 1,000 & 2,000 & 1,500 \\
\hline
\end{tabular}


Table 2. L9 orthogonal array

\begin{tabular}{lccc}
\hline & \multicolumn{3}{c}{ Parameter Level } \\
\cline { 2 - 4 } $\begin{array}{l}\text { Manufacturing } \\
\text { run no. }\end{array}$ & Temperature & $\begin{array}{c}\text { Stirring } \\
\text { speed }\end{array}$ & $\begin{array}{c}\mathrm{TiH}_{2} \\
\text { fraction }\end{array}$ \\
\hline 1. & 1 & 1 & 1 \\
2. & 1 & 2 & 2 \\
3. & 1 & 3 & 3 \\
4. & 2 & 1 & 2 \\
5. & 2 & 2 & 3 \\
6. & 2 & 3 & 1 \\
7. & 3 & 1 & 3 \\
8. & 3 & 2 & 1 \\
9. & 3 & 3 & 2 \\
\hline
\end{tabular}

The traditional DOE solution requires one to use a complete factorial method where there are two or more control variables present. Such an experiment takes into consideration all the levels and their combinations of process parameters which have been selected and gives us the opportunity to study each factor's effect on the response variable. However, this approach can be very difficult where a large number of variables are considered. The Taguchi approach enables us solve the issue by helping to analyze the whole parameter space through utilizing only a portion of the overall number of trials required for a full factorial evaluation described in detailed form in [37], so L9 orthogonal array was establisehed to execute the experimental runs, see in Table 2.

After the production, the samples were cut down to $30 \times$ $30 \times 30 \mathrm{~mm}$ cubes (Fig. 1) using a cutting machine in accordance with the ISO 13314 standard [38].

Image analysis was executed on the foam specimens using ImageJ software which begins by taking pictures of the specimens from the same distance and from the same

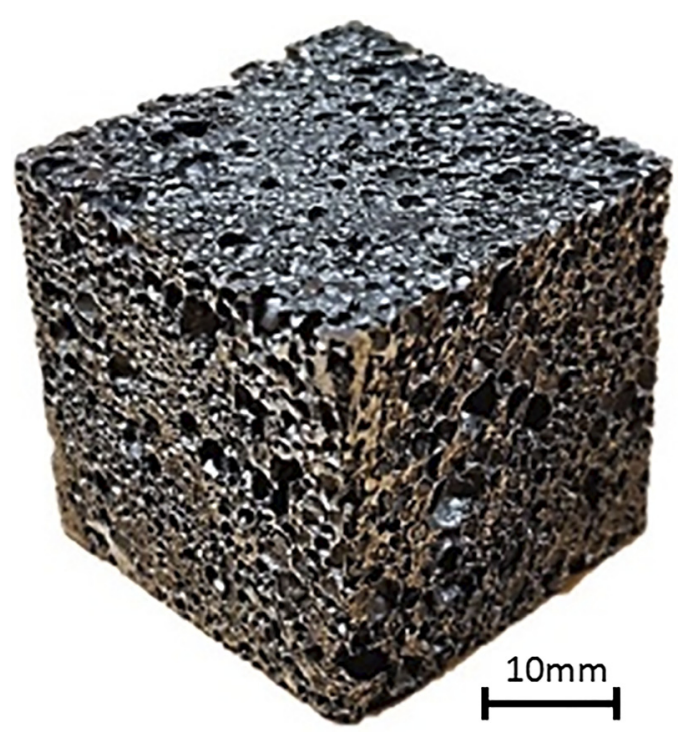

Fig. 1. Aluminum foam specimen prepared according to ISO 13314 standard

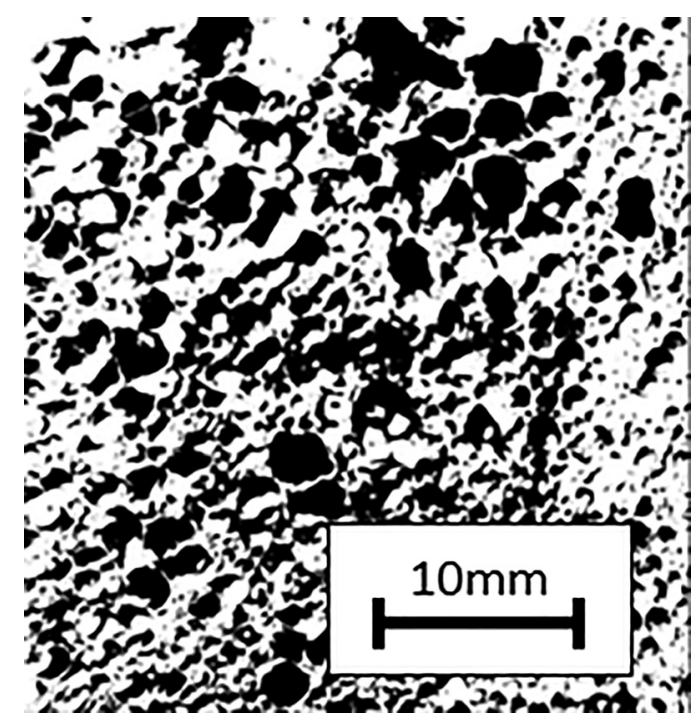

Fig. 2. Binary image of aluminum foam

source, so that the pixels do not change. Each sample provides us with 6 pictures as it has 6 different surfaces. Furthermore, the ImageJ software was calibrated (59.1 pixels $/ \mathrm{mm}$ ) with the known distance to take the pictures in order to convert the pixels into $\mathrm{mm}$ which enables us to find the pore size in $\mathrm{mm}$.

In order to find the porous area, contrast was enhanced to $1.2 \%$ to make the image more clear and then the image was converted into a binary image as shown in Fig. 2 so that the pores and the solid parts can be distinguished from each other. The pore area is then calculated through the software using the images obtained from each surface. The average of the result obtained from each surface gives us the average porous area of the complete sample.

The average pore size for each specimen has also been calculated through the ImageJ software, by taking at least ten pores from each binary image. The binary image was zoom on the pore which size needs to be calculated and then multiple lines must be drawn on that pore to find the average pore size. This results in an average value of the pore size for each specimen using a total of almost sixty pores from one sample. Moreover, since the pores are not exactly circular or even, multiple lines have been drawn from one end of the pore to another to find the average size of each individual pore (Fig. 3).

\section{RESULTS AND DISCUSSION}

The average pore size and the average porous area of the nine specimens found by the above-mentioned method are listed in Table 3.

The Taguchi analysis was carried out using Minitab statistical software on the data collected for the average pore size and the average porous area of the foam specimens. Seeing that the average pore size for the closed cell aluminum foams has to be as minimal as possible, the smaller-the-better output 


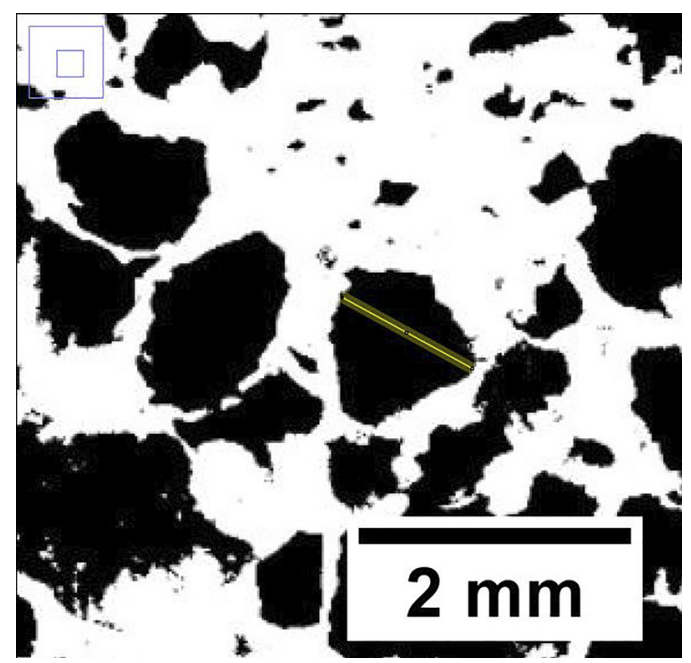

Fig. 3. Calculation of pore size by drawing lines

Table 3. Aluminum foam specimen average pore size and porosity

\begin{tabular}{lccccc}
\hline & \multicolumn{3}{c}{ Parameter level } & & \\
\cline { 2 - 4 } $\begin{array}{l}\text { Run } \\
\text { no. }\end{array}$ & $\begin{array}{c}\text { Temp } \\
\left({ }^{\circ} \mathrm{C}\right)\end{array}$ & $\begin{array}{c}\text { Mixing } \\
\text { speed } \\
(\mathrm{rpm})\end{array}$ & $\begin{array}{c}\mathrm{TiH}_{2} \\
\text { fraction } \\
(\mathrm{wt} \%)\end{array}$ & $\begin{array}{c}\text { Avg. pore } \\
\text { size }(\mathrm{mm})\end{array}$ & $\begin{array}{c}\text { Avg. } \\
\text { porous } \\
\text { area (\%) }\end{array}$ \\
\hline 1. & 700 & 1,000 & 1.0 & 4.54 & 61.47 \\
2. & 700 & 2,000 & 1.5 & 4.22 & 57.55 \\
3. & 700 & 1,500 & 2.0 & 5.10 & 54.47 \\
4. & 800 & 1,000 & 1.5 & 4.44 & 58.21 \\
5. & 800 & 2,000 & 2.0 & 4.65 & 52.92 \\
6. & 800 & 1,500 & 1.0 & 4.48 & 60.90 \\
7. & 850 & 1,000 & 2.0 & 4.95 & 55.27 \\
8. & 850 & 2,000 & 1.0 & 2.66 & 63.14 \\
9. & 850 & 1,500 & 1.5 & 4.15 & 58.07 \\
\hline
\end{tabular}

criterion was selected for the study. Figure 4 shows the main effects plot of the means.

The average porous area needs to be as high as possible so higher the better output criterion was chosen for that study and the obtained main effects plots for the mean and the signal-to-noise ratio $(\mathrm{S} / \mathrm{N})$ are shown in Figs 5 and 6, respectively.

Figure 4 indicates that the average pore size response of aluminum foam is minimum at $850{ }^{\circ} \mathrm{C}$ applied temperature, 2,000 rpm stirring speed and $1 \mathrm{wt} \%$ of $\mathrm{TiH}_{2}$. Figure 5 shows that the average porous area will be maximum at $850{ }^{\circ} \mathrm{C}$ applied temperature, $1,000 \mathrm{rpm}$ stirring speed and $1 \mathrm{wt} \%$ of $\mathrm{TiH}_{2}$. Furthermore, Fig. 6 refers to the settings when the process is less responsive to variation. These settings correspond to; $850{ }^{\circ} \mathrm{C}, 1,000 \mathrm{rpm}$, and $1.0 \mathrm{wt} \%$ foaming agent. Stirring speed has a greater effect on the reduction of the average pore size rather than on porosity or on the $S / N$ ratio. Hence, setting the stirring speed up to $2,000 \mathrm{rpm}$ would allow one to reduce the pore size without having much effect on the porous area and the porous area $\mathrm{S} / \mathrm{N}$ ratio.

In order to confirm the optimal parameters usually we do a confirmation experiment but, in our case, it is not required as the optimal process parameter setting already corresponds to sample no. 8 as shown in Table 4 . It can be also clearly seen that these parameters will provide a high porous area along with the minimum pore size for the aluminum foam.

The response of means of average pore size are shown in Table 4 whereas the response for means and $\mathrm{S} / \mathrm{N}$ ratio of average porous area are presented in Tables 5 and 6, respectively. These results show the average response at each level of the factors and the difference between the highest and the lowest average response value of each factor (Delta), telling us about the dominant factors which affect the means and the $\mathrm{S} / \mathrm{N}$ ratio of the response. In both (average

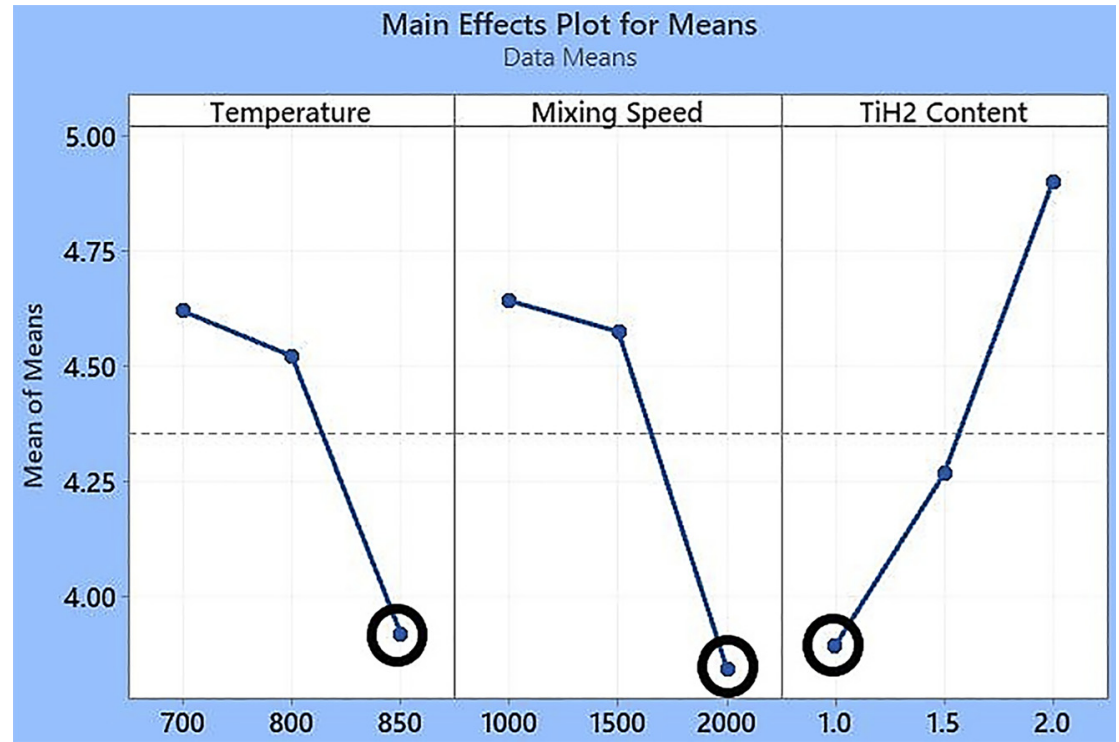

Fig. 4. Main effects plot for means of average pore size 


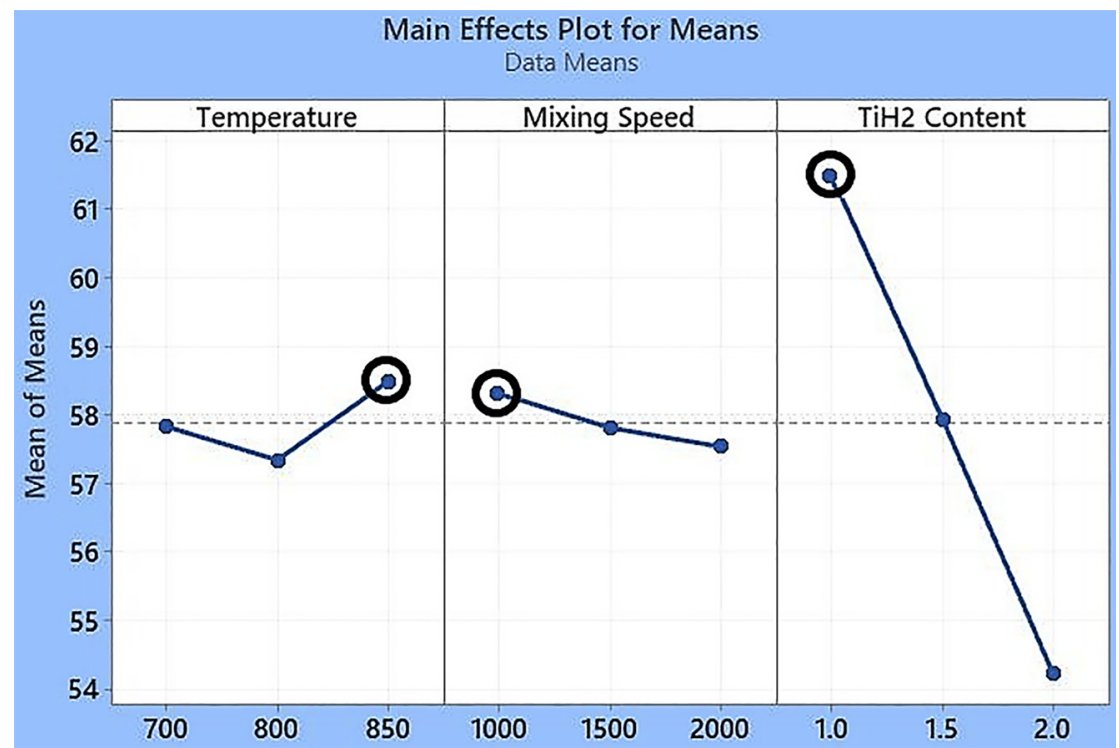

Fig. 5. Main effects plot for means of average porous area

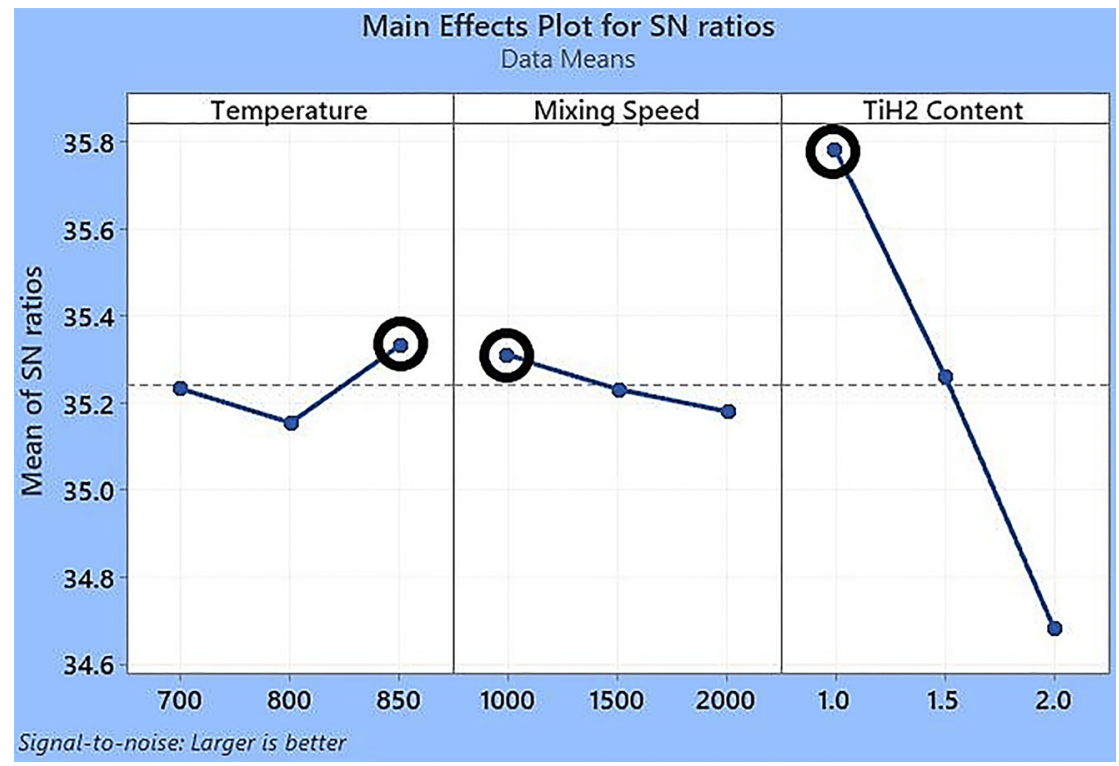

Fig. 6. Main effects plot for $\mathrm{S} / \mathrm{N}$ ratios of average porous area

Table 4. Response for means of average pore size

\begin{tabular}{lccc}
\hline Level & Temperature & Stirring speed & $\mathrm{TiH}_{2}$ content \\
\hline 1 & 4.620 & 4.642 & 3.893 \\
2 & 4.522 & 4.575 & 4.267 \\
3 & 3.918 & 3.843 & 4.900 \\
Delta & 0.701 & 0.798 & 1.006 \\
Rank & 3 & 2 & 1 \\
\hline
\end{tabular}

Table 5. Response for means of average porous area

\begin{tabular}{lccc}
\hline Level & Temperature & Stirring speed & $\mathrm{TiH}_{2}$ content \\
\hline 1 & 57.83 & 58.32 & 61.50 \\
2 & 57.34 & 57.81 & 57.94 \\
3 & 58.49 & 57.54 & 54.22 \\
Delta & 1.15 & 0.78 & 7.28 \\
Rank & 2 & 3 & 1 \\
\hline
\end{tabular}

Table 6. Response for $\mathrm{S} / \mathrm{N}$ ratio of average porous area

\begin{tabular}{lccc}
\hline Level & Temperature & Stirring speed & $\mathrm{TiH}_{2}$ content \\
\hline 1 & 35.23 & 35.31 & 35.78 \\
2 & 35.15 & 35.23 & 35.26 \\
3 & 35.33 & 35.18 & 34.68 \\
Delta & 0.18 & 0.13 & 1.10 \\
Rank & 2 & 3 & 1 \\
\hline
\end{tabular}

Table 7. Results for average porous area

\begin{tabular}{lcrrrr}
\hline & DF & Adj SS & Adj MS & F-value & $P$-value \\
\hline Temperature & 2 & 2.0013 & 1.0007 & 2.16 & 0.316 \\
mixing speed & 2 & 0.9357 & 0.4679 & 1.01 & 0.497 \\
TiH $_{2}$ content & 2 & 79.6203 & 39.8102 & 85.95 & 0.012 \\
Error & 2 & 0.9263 & 0.4632 & & \\
Total & 8 & 83.4837 & & & \\
\hline
\end{tabular}




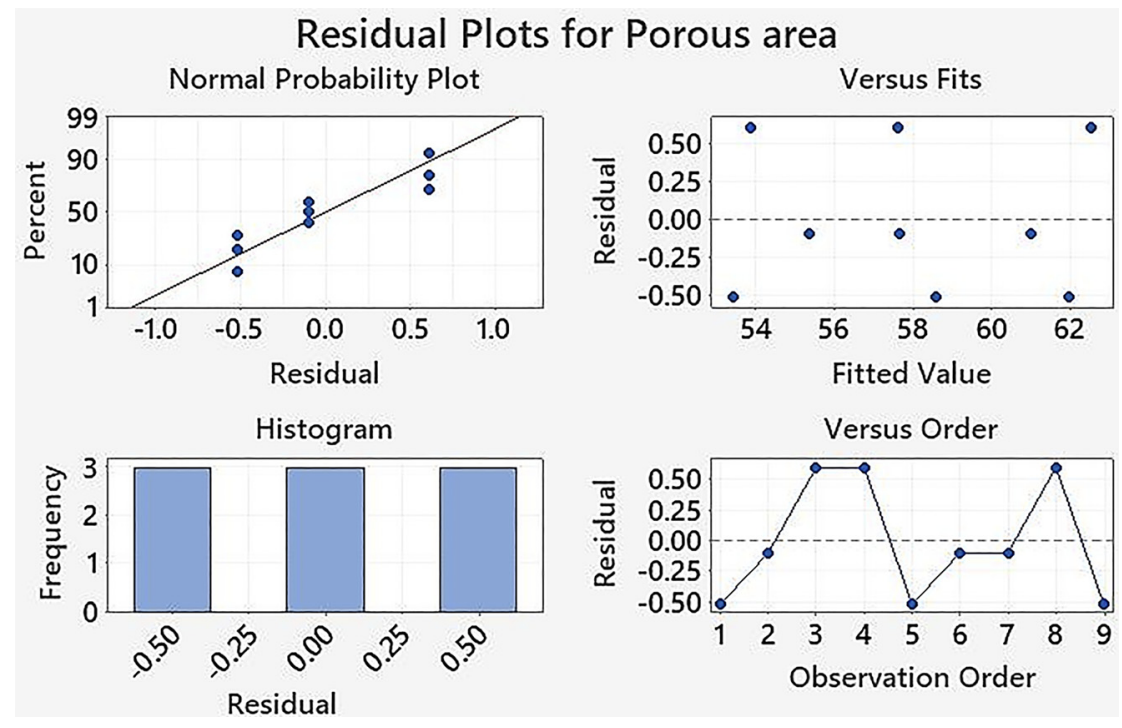

Fig. 7. Residual Plots for average porous area

pore size and porous area) cases $\mathrm{TiH}_{2}$ is the most dominant factor in means and $\mathrm{S} / \mathrm{N}$ ratio.

In addition, to assess the importance of the association between the control variables and the average porous area of the aluminum foam samples, ANOVA statistical analysis was performed, findings of which can be seen in Table 7. DF (degree of freedom), AdjSS (adjusted sums of squares) and Adj MS (adjusted mean squares) are the residuals versus variables, order and fits, respectively. F-value is the test statistic, while $P$-value is the probability.

To see if the factor is statistically significant or not, the level of the significance has to be compared to the $P$-value. Typically, significance level ( $\alpha$ or alpha) of 0.05 works well. From Table 7 it can be clearly inferred that $\mathrm{TiH}_{2}$ content is the only significant control factor (95\% confidence level) associated with the average porous area characteristic of the produced samples. The errors show that there might exist an interaction between the control factors that might affect our response variable.

The residual plots of the average porous area obtained as a result of performing ANOVA are shown in Fig. 7. The residuals are the deviation between the experimental value and the theoretical value, the plots of which shows the fitted values that are residual and theoretical value. Lower and upper range fitted values from zero residual and variation in residuals in all experiments are also shown. We can observe that these residuals usually coincide on a straight line which indicates errors. Therefore, it can be inferred that there is no obvious pattern, and there is no model scarcity in the residual analysis.

\section{CONCLUSIONS}

The research goal was to optimize the manufacturing parameters for direct foaming of closed-cell aluminum foams by means of a statistical approach. Therefore, hybrid closed-cell foam samples were produced from aluminum raw material according to the principle of Taguchi DOE through the direct foaming method. A L9 orthogonal array which consists of 9 samples was selected to perform the experiment by changing the production parameters including temperature, amount of foaming agent and stirring speed. Image analysis was conducted to find the specimens' average porous area and pore size. Moreover, to analyze the effect and the significance of the process parameters Taguchi method and the ANOVA statistical analysis were conducted. The investigation determines that the foaming content is the most influential variable reducing the pore size and for the maximizing the porous area of metallic foam, followed by the mixing speed and temperature. The optimum control factor settings obtained to minimize the pore size and to increase the porosity characteristics are: $850{ }^{\circ} \mathrm{C}$ applied temperature, $2,000 \mathrm{rpm}$ for stirring speed and $1 \mathrm{wt} \%$ of $\mathrm{TiH}_{2}$. Additionally, the $\mathrm{TiH}_{2}$ foaming content has a statistically significant influence on the response, with a confidence level of $95 \%$.

\section{REFERENCES}

[1] M. Mukherjee, F. Garcia-Moreno, and J. Banhart, "Collapse of aluminum foam in two different atmospheres," Metall. Mater. Trans. B, vol. 41, no. 3, pp. 500-4, 2010, https://doi.org/10.1007/ s11663-010-9357-5.

[2] A. G. Evans, J. W. Hutchinson, and M. F. Ashby, "Multifunctionality of cellular metal systems," Prog. Mater. Sci., vol. 43, no. 3, pp. 171-221, 1998, https://doi.org/10.1016/S0079-6425(98) 00004-8.

[3] V. S. Deshpande and N. A. Fleck, "High strain rate compressive behaviour of aluminium alloy foams," Int. J. Impact Eng., vol. 24, no. 3, pp. 277-98, 2000, https://doi.org/10.1016/S0734-743X(99) 00153-0. 
[4] A. E. Markaki and T. W. Clyne, "The effect of cell wall microstructure on the deformation and fracture of aluminium-based foams," Acta Materialia, vol. 49, no. 9, pp. 1677-86, 2001, https:// doi.org/10.1016/S1359-6454(01)00072-6.

[5] V. Kevorkijan, S. D. Škapin, I. Paulin, B. Šuštaršič, and M. Jenko, "Synthesis and characterisation of closed cells aluminium foams containing dolomite powder as foaming agent," Mater. Tehnol., vol. 44, no. 6, pp. 363-71, 2010.

[6] V. C. Shunmugasamy and B. Mansoor, "Compressive behavior of a rolled open-cell aluminum foam,” Mater. Sci. Eng. A, no. 715, pp. 281-94, 2018, https://doi.org/10.1016/j.msea.2018.01.015.

[7] J. Banhart, "Aluminium foams for lighter vehicles," Int. J. Vehicle Des., vol. 37, nos 2-3, pp. 114-25, 2005, https://doi.org/10.1504/ IJVD.2005.006640.

[8] M. Peroni, G. Solomos, and V. Pizzinato, "Impact behaviour testing of aluminium foam," Int. J. Impact Eng., vol. 53, pp. 74-83, 2013, https://doi.org/10.1016/j.ijimpeng.2012.07.002.

[9] O. B. Olurin, N. A. Fleck, and M. F. Ashby, "Indentation resistance of an aluminium foam," Scr. Mater., vol. 43, no. 11, pp. 983-9, 2000.

[10] B. Yang, L. Tang, Y. Liu, Z. Liu, Z. Jiang, and D. Fang, "Localized deformation in aluminium foam during middle speed Hopkinson bar impact tests,” Mater. Sci. Eng. A, no. 560, pp. 734-43, 2013, https://doi.org/10.1016/j.msea.2012.10.027.

[11] K. Y. McCullough, N. A. Fleck, and M. F. Ashby, "Uniaxial stressstrain behaviour of aluminium alloy foams," Acta Mater., vol. 47, no. 8, pp. 2323-30, 1999, https://doi.org/10.1016/S1359-6454(99) 00128-7.

[12] Y. Yao, H. Wu, and Z. Liu, "A new prediction model for the effective thermal conductivity of high porosity open-cell metal foams," Int. J. Therm. Sci., no. 97, pp. 56-67, 2015, https://doi.org/ 10.1016/j.ijthermalsci.2015.06.008.

[13] R. E. Raj and B. S. S. Daniel, "Aluminum melt foam processing for light-weight structures," Mater. Manuf. Process., vol. 22, no. 4, pp. 525-30, 2007, https://doi.org/10.1080/1042691070 1236072.

[14] N. Novak, M. Vesenjak, and Z. Ren, "Auxetic cellular materials-a review,” Stroj. Vestn-J. Mech. Eng., vol. 62, no. 9, pp. 485-93, 2016, https://doi.org/10.5545/sv-jme.2016.3656.

[15] M. A. De Meller, "Produit métallique pour l'obtention d'objets laminés, moulés ou autres, et procédés pour sa fabrication," French Patent, vol. 615, no. 147, 1926.

[16] J. Banhart, "Metal foams: production and stability," Adv. Eng. Mater., vol. 8, no. 9, pp. 781-94, 2006, https://doi.org/10.1002/ adem.200600071.

[17] M. F. Ashby, T. Evans, N. A. Fleck, J. W. Hutchinson, H. N. G. Wadley, and L. J. Gibson, Metal Foams: A Design Guide. Elsevier, 2000.

[18] A. A. Gokhale, N. V. Kumar, B. Sudhakar, S. N. Sahu, H. Basumatary, and S. Dhara, "Cellular metals and ceramics for defence applications,” Defence Sci. J., vol. 61, no. 6, 2011.

[19] K. Vikas, N. R. Ram, C. K. Reddy, and V. V. Raju, "Process parameters and foaming agents used in manufacturing of aluminium metallic foams: a review," Int. J. Sci. Eng. Technol., vol. 4, no. 11, pp. 505-10, 2015.

[20] I. N. Orbulov, J. Dobranszky, and A. Nemeth, "Microstructural characterisation of syntactic foams," J. Mater. Sci., vol. 44, no. 15, pp. 4013-9, 2009, https://doi.org/10.1007/s10853-009-3552-2.
[21] I. N. Orbulov and A. Szlancsik, "On the mechanical properties of aluminum matrix syntactic foams," Adv. Eng. Mater., vol. 20, no. 5, p. 1700980, 2018, https://doi.org/10.1002/adem.201700980.

[22] A. Stręk, "Methodology for experimental investigations of metal foams and their mechanical properties," Mech. Control, vol. 31, no. 2, p. 90, 2012, https://doi.org/10.7494/mech.2012.31.2.90.

[23] B. Nečemer, M. Vesenjak, and S. Glodež, "Fatigue of cellular structures-a review," Stroj. Vestn/J. Mech. Eng., vol. 65, no. 9, 2019, https://doi.org/10.5545/sv-jme.2019.6070.

[24] B. Jiang, Z. Wang, and N. Zhao, "Effect of pore size and relative density on the mechanical properties of open cell aluminum foams," Scr. Mater., vol. 56, no. 2, pp. 169-72, 2007, https://doi. org/10.1016/j.scriptamat.2006.08.070.

[25] C. Suresh and S. Vidyashankar, "Investigation of the effect of pore size on mechanical properties of open cell aluminium foam structure," Int. J. Adv. Eng. Manag. Sci., vol. 2, no. 9, 2016.

[26] X. C. Xia, X. W. Chen, Z. Zhang, X. Chen, W. M. Zhao, B. Liao, and B. Hur, "Effects of porosity and pore size on the compressive properties of closed-cell Mg alloy foam," J. Magnes. Alloys, vol. 1, no. 4, pp. 330-5, 2013, https://doi.org/10.1016/j.jma.2013.11.006.

[27] A. Gábora and T. Mankovits, "Quality control of closed-cell metal foam produced by direct foaming," IOP Conf. Ser. Mater. Sci. Eng., vol. 659, no. 1, Paper 012037, 2019.

[28] R. Surace, L. A. De Filippis, A. D. Ludovico, and G. Boghetich, "Experimental analysis of the effect of control factors on aluminium foam produced by powder metallurgy," Estonian $J$. Eng., vol. 13, no. 2, 2007.

[29] R. Surace, L. A. De Filippis, A. D. Ludovico, and G. Boghetich, "Application of Taguchi method for the multi-objective optimization of aluminium foam manufacturing parameters1," Int. J. Mater. Form., vol. 3, no. 1, pp. 1-5, 2010, https://doi.org/10.1007/ s12289-009-0409-9.

[30] F. Garai, G. Béres, and Z. Weltsch, "Development of tubes filled with aluminium foams for lightweight vehicle manufacturing," Mater. Sci. Eng. A-Struct. Mater. Prop. Microstruct. Process., vol. 790, Paper 139743, 2020, https://doi.org/10.1016/j.msea.2020. 139743.

[31] F. Garai, F. Hareancz, and Z. Weltsch, "Novel application of metal foams: aluminium foam-filled tubes," Perner's Contact, vol. 2, no. 19, pp. 85-92, 2019.

[32] E. Kilickap, "Optimization of cutting parameters on delamination based on Taguchi method during drilling of GFRP composite," Expert Syst. Appl., vol. 37, no. 8, pp. 6116-22, 2010, https://doi. org/10.1016/j.eswa.2010.02.023.

[33] S. S. Mahapatra and A. Patnaik, "Parametric optimization of wire electrical discharge machining (WEDM) process using Taguchi method," J. Braz. Soc. Mech. Sci. Eng., vol. 28, no. 4, pp. 422-9, 2006, https://doi.org/10.1590/S1678-58782006000 400006.

[34] S. S. Madaeni and S. Koocheki, "Application of taguchi method in the optimization of wastewater treatment using spiral-wound reverse osmosis element," Chem. Eng. J., vol. 119, no. 1, pp. 37-44, 2006, https://doi.org/10.1016/j.cej.2006.03.002.

[35] P. Vijian and V. P. Arunachalam, "Optimization of squeeze cast parameters of LM6 aluminium alloy for surface roughness using Taguchi method," J. Mater. Process. Technol., vol. 180, nos 1-3, pp. 161-6, 2006, https://doi.org/10.1016/j.jmatprotec. 2006.05.016. 
[36] T. Mankovits, I. Budai, G. Balogh, A. Gábora, I. Kozma, T. Varga, and I. Kocsis, "Structural analysis and its statistical evaluation of a closed-cell metal foam," Int. Rev. Appl. Sci. Eng., vol. 5, no. 2, pp. 135-43, 2014.

[37] M. A. Naeem, A. Gábora, and T. Mankovits, "Influence of the manufacturing parameters on the compressive properties of closed cell aluminum foams," Period. Polytech. Mech. Eng., vol. 64 , no. 2, pp. 172-8, 2020, https://doi.org/10.3311/PPme. 16195.

[38] ISO 13314 (2011), Mechanical Testing of Metals-Ductility TestingCompression Test for Porous and Cellular Metals. Geneva, Switzerland: ISO, 2011.

Open Access. This is an open-access article distributed under the terms of the Creative Commons Attribution 4.0 International License (https://creativecommons.org/ licenses/by/4.0/), which permits unrestricted use, distribution, and reproduction in any medium, provided the original author and source are credited, a link to the CC License is provided, and changes - if any - are indicated. (SID_1) 